\title{
The Pacific Alliance Towards a Strategy on Digital Economy?*
}

Received: September 7, 2018

Approved: October 11, 2019

Doi: https://doi.org/10.12804/revistas.urosario.edu.co/acdi/a.8343

\section{Guillermo Rodrigo Corredor C.*}

Abstract: Countries of the Pacific Alliance (PA) share a common interest in the development of a regional regulatory framework that can give impetus to the dynamism of the embryonic digital economy in the region. The trend towards the progressive implementation of new and stricter rules on e-commerce fosters increments in foreign investment and generation of spill-over effects. However, the preference for the models inspired by the FTAs negotiated by the United States, as well as an inclination for self-regulation schemes, reflect the dominant role of the private sector

* The author wishes to express his appreciation to professor Susan Ariel Aaronson for her valuable comments on the preliminary version of this article.

** Lawyer and specialist in Intellectual Property from the Universidad Externado de Colombia. Specialist in Public Management and Administrative Institutions from the Universidad de los Andes. Master in International Economic Law from the University of Bern (World Trade Institute). He is currently a teacher and researcher at the Department of Economic Law of the Universidad Externado de Colombia and Visiting Researcher at the Centre de Sciences Humaines in New Delhi. E-mail: rodrigo.corredor@uexternado. edu.co

This article is part of the activities of the research line in international economic law (integration law) within the Research Group in Law and Economics of Universidad Externado de Colombia. The research that supports this article was not financially supported. Any errors or inaccuracies are the sole responsibility of the author.

To cite this article: Corredor, Guillermo Rodrigo. "The Pacific Alliance Towards a Strategy on Digital Economy?" Anuario Colombiano de Derecho Internacional (ACDI) 13, (2020): 165-186. https://doi.org/10.12804/ revistas.urosario.edu.co/acdi/a.8343 
in the negotiations within the PA. This scenario raises essential doubts about the institutional model of the Alliance and its suitability to frame sustainable solutions to the complex social and economic consequences derived from the deepening of the digital economy.

Keywords: Regional integration, digital economy, institutional design, regulation.

\section{¿La Alianza del Pacífico hacia una estrategia en la economía digital?}

Resumen: los países de la Alianza del Pacífico (AP) comparten un interés común en el desarrollo de un marco regulatorio regional que les permita estimular la todavía embrionaria economía digital en la región. La tendencia hacia una implementación progresiva de nuevas y más estrictas reglas en materia de comercio electrónico parece ser el eje para el fomento de mayor inversión extranjera en el sector. Sin embargo, la preferencia por los modelos inspirados en los TLC negociados por Estados Unidos, así como una inclinación por los esquemas de autorregulación, reflejan el papel dominante del sector privado en las negociaciones dentro de la AP. Este escenario plantea serias dudas sobre el modelo institucional de la AP y su idoneidad para enmarcar soluciones sostenibles a las complejas consecuencias sociales y económicas resultantes de la expansión de la economía digital.

Palabras clave: integración regional, economía digital, diseño institucional, regulación.

\section{A Aliança do Pacífico para uma estratégia na economia digital?}

Resumo: os países da Aliança do Pacífico (AP) compartilham um interesse comum no desenvolvimento de um marco regulatório regional que lhes permita estimular a, ainda embrionária, economia digital na região. A tendência para uma implementação progressiva de novas e mais rigorosas regras em matéria de comércio eletrônico parece ser o eixo para o fomento de maior investimento estrangeiro no setor. No entanto, a preferência 
pelos modelos inspirados nos TLC negociados pelos Estados Unidos, assim como uma clara predileção pelos esquemas de autorregulação, refletem o papel dominante do setor privado nas negociações dentro da AP. este cenário apresenta sérias dúvidas sobre o modelo institucional da Aliança e sua idoneidade para enquadrar soluções sustentáveis às complexas consequências sociais e económicas resultantes da expansão da economia digital.

Palavras-chave: integração regional, economia digital, desenho institucional, regulação.

\section{Introduction}

The increasing efforts of governments to tackle the disruptive effects of digitalization are reflecting the underlying difficulties of adapting legal frameworks to the fast, technological changes embedded in the digital economy. In developed countries, the concerns are mainly associated with the need to introduce radical changes in areas where well-established public policies have delivered positive results in terms of welfare (inclusion and access to opportunities, employment, education, professional training). In these countries, the digital economy is associated with the advent of artificial intelligence and its likely damaging effects on labor and social welfare. Large sectors of the population also associated it with drastic and expensive changes necessary for the adaptations of educational and social systems in order to fetch the new skills required to work in direct competition with machines. ${ }^{1}$

\footnotetext{
1 According to Altenburg and Assmann (2017) "Two factors are particularly important to understand these trends: labor-saving technological progress and globalization (Rodrik 2014). New technologies are greatly considerably reducing the demand for routine labor activities in manufacturing and services (Brynjolfsson \& McAfee 2014). For the Us, Frey and Osborne (2013) calculate that about $47 \%$ of jobs are susceptible to computerization in the next 1-2 two decades. Applying the same methodology to developing countries, the World Development Report 2016 found even higher automation potentials -i.e. two thirds of today's jobs in developing countries could be lost to automation- but assumes that automation will proceed more slowly due to time lags in technology adoption (World Bank 2016, 219). In the past, reallocating workers from low productivity agriculture to export-oriented light manufacturing activities was a powerful driver of industrialization and productivity growth" (p. 4).
} 
In contrast, for many developing countries, digitalization is mostly perceived as a driver for wealth and inclusion. It is often promoted as a new way of improving the efficiency of both private and public sectors and of enhancing participation for all in public debates. Thus, automatization is not perceived as a factor hindering employment or leading to deindustrialization; all the possible drawbacks are disregarded in the view of the potential benefits that can be obtained from digital transformation. Industries, which play an ambiguous role in participating and promoting collaborative schemes that allow governments to "deliver" connectivity and progress in remote and poor areas, often encourage this naïve attitude.

Against these contrasted perceptions background, digital transformation is increasingly becoming a source of political tension. One example is the attitudes of European citizens regarding the treatment of personal information or the claims on the worsening on employment rates and job quality linked to the increasing activity of digital platforms. All this is contributing to transform the common positive view of the internet as a driver of economic development into a wide-spread feeling of dissatisfaction and requests to endorse adequate regulations that ensure the right balance between the free flow of information and the protection of fundamental rights. ${ }^{2}$ The adoption on May 6th, 2015, of the European Digital Single Market Strategy (EU-SDM) reflects the extent of the concerns linked to these issues.

For the purpose of the analysis presented in this paper, the DSM approach is relevant as it may serve as a template for Regional Trade Agreements like the PA, whose country members are currently part of staling initiatives like $\mathrm{TISA}^{3}$ or also participating inside active frameworks

2 In this regard, Mohamed El-Erian signals: "To the extent that technology companies are reaching systemic importance, attitudes towards them change markedly. This change has become increasingly evident in recent years, when major technology firms faced greater scrutiny of their competitive practices, their tax behaviour, their use of data and privacy policies. Broader issues have also arisen about their contribution to labour displacement and the effects on wage growth, even as societies increasingly recognize that technological disruption implies the need for educational reform and improvements in the acquisition and reformulation of skills" (author's translation). El-Erian, Mohamed, and Project Syndicate. Las grandes tecnológicas se topan con el Gran Gobierno. Last modified November 6, 2017. https://es.weforum.org/agenda/2017/11/las-grandes-tecnologicasse-topan-con-el-gran-gobierno/

3 See Trade in Services Agreement (TiSA). All members of the PA were part of the TiSA negotiations. TisA is a plurilateral agreement on trade in services, negotiations on which 
like the recently revitalized CРТPP. ${ }^{4}$ From this perspective, one might argue that the main interest of the PA members consists in the preservation of enough regulatory space in order to react to the potential abuses from the tech giants.

On the other hand, while tensions regarding the so-called EU-U.S. Privacy Shield were often perceived as clear signals toward the end of the global internet "as we know it", the practical solutions negotiated by both trade giants reflect an underlying acceptance in respect to the fact that convergence between the two systems is achievable in the long term. This is one way to ensure the influence of western nations in the conceptual basis of the digital economy for years to come. ${ }^{5}$

This paper aims to assess the suitability of the stated architecture of the PA in the context of the challenges brought by the development of the digital economy. The undisputable need to frame activities of new actors and understand the novel rationale of the exchanges taking place in digital ecosystems constitutes a challenge for national authorities inside their territories as well as in the context of economic integration initiatives. From this perspective, achieving coherence through common and institutionalized rules is less likely to happen into an informal/flexible framework as proposed by the PA.

The paper is as follows: the first part introduces the main features of the EU-SDM strategy by stressing the importance of jurisdictional decisions regarding the adequacy of privacy standards in other jurisdictions.

began in 2011 at the initiative of the Us and Australia. https://www.bilaterals.org/?tisadraft-annex-on-electronic-32465\&lang $=$ en

4 See Comprehensive and Progressive Agreement for Trans-Pacific Partnership (CPTPP). This agreement is a separate treaty that incorporates, by reference, the provisions of the Trans-Pacific Partnership (TPP) Agreement (signed but not yet in force), with the exception of a limited set of suspended provisions. The 11 countries have a shared vision of the CРTPP as a platform that is open to others to join if they are able to meet its high standards. https://dfat.gov.au/trade/agreements/in-force/cptpp/ Pages/comprehensive-and-progressive-agreement-for-trans-pacific-partnership.aspx

5 In its Report to the European Parliament and the Council on the second annual review of the functioning of the EU-Us Privacy Shield the Commission took into account “... relevant developments in the Us legal system in the area of privacy. This concerns, in particular, the consultation initiated by the Department of Commerce on a federal approach to data privacy as well as the Federal Trade Commission's process of reflection on its current powers in the area of privacy and the efficacy of the use of its current remedial authority." 
The second part focuses on ascertaining if there is an approach defined by the PA regarding the so-called Internet fragmentation focusing on the underlying problem of institutionalized frameworks absence to deal with complex issues such as digital data flows embedded in the provision of digital services. In this sense, the paper assesses alternatives for legal reviewing of practices linked to the digital economy through existing legal institutions such as the Andean Tribunal of Justice (ATJ) of the Andean Community (AC). The final section concludes with the way forward to build up a strategy to deal with digital platforms and make of them a driver for economic development for the PA countries.

\section{The EU-SDM Strategy}

The declared aim of the EU-SDM strategy, consisting in "open[ing] up digital opportunities for people and business, and enhance Europe's position as a world leader in the digital economy," "reflects a tacit recognition of fragmentation of the Internet both from a technical and regulatory point of view. ${ }^{7}$ In this sense, the EU's approach to digitalization is, to a certain extent, friendly to the embracement of the WTO principles and rules of international economic law. Aaronson correctly points out this fact in the following quote:

After deliberating for months, the EU announced its approach to digital trade and digital protectionism in February 2018. The strategy has personal data protection at its core. In its trade agreements $(. .$.$) , the$

\footnotetext{
6 https://ec.europa.eu/digital-single-market/

7 Fragmentation must be understood as the possibility to create new realms of interpretation, which can affect the underlying functioning of a system. In the case of the Internet, the extraterritorial application of specific standards increases the transaction costs inside markets subject to different economic rationality. This is reflected in the analysis proposed by Atkinson in 2017 (quoted by Aaronson) “... EU approach to elevating data protection is attractive to many countries and netizens, but, on the other hand, it is extremely costly to digital firms. Despite these costs and benefits, the EU increasingly encourages its trade partners to accept its approach to data protection. In 2017, a French court required that websites outside of France must block foreign content to enforce the EU's 'right to be forgotten'. In so doing, the EU is imposing its values on other suppliers and consumers of data." Susan Ariel Aaronson, "What Are We Talking about When We Talk about Digital Protectionism?”, World Trade Review, n. d., 20. https:/doi.org/10.1017/ S1474745618000198
} 
EU will insist on three pillars: (1) a horizontal clause covering the free flow of both personal and non-personal data; (2) a ban on data and server localization requirements; and (3) language that safeguards the EU's right to regulate personal data, including language that the first two pillars cannot be subject to investor-state challenges or included in regulatory dialogues. In so doing, the EU made it clear that its vision of data protection cannot be challenged as a barrier to trade... ${ }^{8}$

Beyond the economic or political significance of this position —which includes obviously the emphasis on personal data protection ${ }^{9}$ its importance lies in the ability to maintain a coherent legal framework built on the experiences coming from the different EU jurisdictions and legal traditions. ${ }^{10}$ This circumstance is relevant as data has become "the

8 Aaronson, "What Are We Talking about When...

$9 \quad$ As reiterated by the EU Commission in 2018: "More and more countries around the world are realising that robust data protection and privacy rules not only ensure fundamental rights, but generate trust in the digital economy. As a result, many are adopting or modernising privacy laws. And often the General Data Protection Regulation serves as an inspiration, with the EU rules setting a global standard for data protection and privacy. Currently the Commission is exploring adequacy decisions with Japan and South Korea, which would mean that personal data transferred to these countries from the EU would enjoy the same level of protection and rights of redress as in the EU itself. (...) At the same time, the Commission has developed an approach on how the EU can tackle, through trade and investment agreements, protectionist practices as regards cross-border data flows in the digital economy while ensuring that the right to protect personal data and privacy is fully preserved. This approach, once included in the EU's trade and investment agreements, will foster both free flows of data and trust in the way personal data are processed. European Commission. Communication from the Commission to the European Parliament, the European Council, the Council, the European Economic and Social Committee and the Committee of the Regions. Completing a trusted Digital Single Market for all, https://ec.europa. eu/newsroom/dae/document.cfm?doc_id $=52283$

10 Three main decisions enlighten the evolutions contained in the new regulation GoogleSpain, Case C-131/12, Google Spain SL and Google Inc. v. Agencia Española de Protección de Datos (AEPD) and Mario Costeja González: Judgment of the Court (Grand Chamber) of 13 May 2014, ECR [2014] 317. Cases C-293 \& C-594/12, Digital Rights Ireland Ltd. v. Minister for Communications, Marine and Natural Resources, Minister for Justice, Equality and Law Reform, Commissioner of the Garda Siochána, Ireland, The Attorney General, and Kärntner Landesregierung, Michael Seitlinger, Christof Tschobl and others, judgment of April 8, 2014, ECR [2014] I-238 and C-362/14, Maximillian Schrems v. Data Protection Commissioner, judgment of October 6, 2015, ECLI:EU:C:2015:650. 
new most valuable resource"11 and, at the same time, somewhat difficult to ascertain for regulators. ${ }^{12}$ The complexity induced by the double simultaneous role of consumers as users and producers of information and the new rationale of exchanges, happening in the digital platforms, challenge the capacity of regulators to guarantee stability and predictability for the future of the digital economy.

As mentioned in the introduction, the EU and the US defensive approach, towards allegedly digital protectionist measures proposed by its trade partners, needs to be analyzed in the light of the increasing pressure coming from emergent economies. These new entrants are currently enjoying incredible economic growth and are likely to become a potential market of millions of people already connected and willing to satisfy their needs through the intensive use of resources available in digital ecosystems.

Against this backdrop of mounting competition, other geopolitical issues are also emerging. The consolidation of China as major and undisputable actor in the digital economy as well as the defying position assumed by countries like Brazil, India or Russia through the enactment of local policies and regulations that can be labeled as "digital protectionism", 13 are factors to be taken into consideration for developing countries, namely those participating in the $\mathrm{PA}$, at the moment of negotiating their legal and technical frameworks or when proposing joint strategies related to the digital economy.

\footnotetext{
11 "The world's most valuable resource", The Economist, May 6, 2017: 7.

12 Despite these inherent difficulties, regulatory processes inside the EU benefit from the greater transparency provided by the institutionalization of procedures within it. Aaronson and Leblond emphasize this fact when they refer to public consultation and dialogues with stakeholders launched by the Commission in order to better understand public concerns related to complex matters such as restrictions on cross border data. Susan Ariel Aaronson and Patrick Leblond, "Another Digital Divide: The Rise of Data Realms and Its Implications for the WTO," Journal of International Economic Law 21, no. 2 (2018): 260.

13 Regarding the extent of this concept Drake et al. explain: "surprised and concerned about the strong statements coming from us sources about regulatory and legislative proposals on the digital agenda for the EU. While many of these are still in very early stages, President Obama spoke of 'digital protectionism', and many in the private sector echo similar words." William J. Drake, Vinton G. Cerf, and Wolfgang Kleinwächter, Future of the Internet Initiative White Paper. Internet Fragmentation: An Overview, World Economic Forum, 2016, 36 .
} 
In sum, the increasing threat of fragmentation or balkanization of the Internet represents a real risk for developed economies that eventually can find themselves excluded from access to promising markets or become simple bystanders of the proliferation of online platforms and applications able to manage data and supply solutions from the south for developing countries. ${ }^{14}$

\section{Where to Go in a Fragmentation Scenario if You Are a Developing Country?}

The leadership of us companies ${ }^{15}$ in the market of the algorithmic treatment of information is at the origin of the main concerns of EU regulators, as well as it is for some developing countries. ${ }^{16}$ Curiously, in the context

14 Regarding Internet fragmentation, Chertoff, points out: "By definition, the internet is ubiquitous, and data flows globally. In reality data must be housed on physical infrastructure and move through routers and over fiber-optic or wireless transmission technology. The question arises as to whose rules apply, and if the location of the infrastructure becomes the guiding principle. This would have the perverse effect of nations either demanding or creating incentives to house servers locally, or in countries with laws most favourable to internet service providers. If each nation demands that data pertaining to its own citizens is stored within its own borders, this could give rise to a fragmentation of the internet. That sort of Balkanization would most certainly lead to engineering inefficiencies and, worse yet, an internet full of gaps and seams." Michael Chertoff, Exploding Data: Reclaiming Our Cyber Security in the Digital Age. (London: Grove Press, 2018), 162.

15 "Eight of the world's most highly valued companies are technology businesses. The combined market capitalization of these companies is $\$ 4.7 \mathrm{tn}$. That is 30 per cent of the combined market capitalization of the other 92 companies in the world's 100 most valuable firms. Of these eight companies, five (Apple, Alphabet, Microsoft, Amazon and Facebook) are from the Us, two are Chinese (Alibaba and Tencent) and one is South Korean (Samsung). The most highly valued European tech company, SAP, is the world's 60th most valued company." Martin Wolf, "Taming the Masters on the Tech Universe", Financial Times, November 14, 2017, https://www.ft.com/content/45092c5c-c872-11e7aa33-c63fdc9b8c6c

16 Drake et al. opinion on the reasons for implementing digital strategies reflects to some extent the current scenario for the PA "Given the economic stakes involved, governments everywhere are working to assess the opportunities and risks and to devise national digital strategies. This includes many governments in the Least Developed Countries. The evidence available in a variety of studies suggests a strong relationship between openness to the Internet and wealth creation. Nevertheless, governments are often tempted to play for time and pursue approaches that preference national/regional players and digital spaces, including by restraining first-moving companies from abroad. In this context, the predo- 
of the PA, this sense of pre-eminence by a handful of tech giants is leading to the proliferation of regulatory measures directed to improve investment conditions rather than to focus on restrictive measures directed to promote or ensure respect for the fundamental rights of their citizens.

This trend can be explained by a sort of "blind reliance" shared by all PA member countries on the ability of big companies to achieve high ethical standards and transform them into self-regulated schemes, which are supposedly sufficient to lead to better outcomes in terms of respect of the rule of law and improvement of welfare conditions. This exaggerated faith in the responsibility of companies is also a good argument for remaining loyal to the paradigm of minimizing the regulatory power of the government for complicating legal and technical issues that the private sector can handle efficiently.

However, the impact of applying this laissez-faire approach to digitalization is reaching its limits. The evidence of undesirable societal outcomes, like those related with the Snowden revelations on NSA's massive surveillance program or the astonishing accusations of Russian influence in the us electoral process, are increasingly calling for a more active role from the State on the activities of enterprises that enjoy outstanding technical and economic power. ${ }^{17}$ Even if some of these interventions could be labeled as digital protectionism, the convenience of their implementation should be considered in the context of the need to preserve the very basis of democracy and global economic stability. Divergent views consider that measures intended to protect privacy, cultural values or some other national strategic interests are not appropriate for the Internet as a global good, they consider that:

Whereas governments' earlier endeavours to increase control over the Internet had the implicit aim of keeping information outside state borders, this new breed of regulation aims at keeping data in. With the pretext of increasing online security and privacy, some governments are requiring mandatory storage of critical data on servers

minance of US technology companies in key market segments has led some governments to consider or adopt laws and regulatory practices that hinder certain kinds of operations and transactions or block the use of particular tools, be it social networking platforms or cross-border delivery via 3D printing." Drake et al. Future of the Internet..., 35.

17 "Do social media threaten democracy? The Economist, November 4, 2017, 11. 
physically located inside the country, i.e. data localisation. Also, some data protection and security laws create barriers to cross-border data transfers to such an extent that they are effectively data localisation requirements (...) Forced localisation is often the product of poor or one-sided economic analysis, with the surreptitious objective of keeping foreign competitors out, or creating a handful of new jobs in e-commerce, data centres or consultancies. However, any job gains as a result of data localisation are minuscule compared to losses in terms of jobs and output in other parts of the economy. ${ }^{18}$

The apparent lucidity of this statement contrasts with the current impacts of digitalization in developing countries. The opacity brought by some digital platforms in some markets and the ability to influence public debates or electoral outcomes are facts that bring some legitimacy to the idea of deploy, the so called industrial policies (including local storage of critical data) in the realm of the algorithmic processing of data as a mean of bearing effective solutions for societal problems and concretize the potential of big data analytics as the driver for modernization of public affairs, the fight against corruption and the improvement of the livelihood of millions of people.

\subsection{A Confused Roadmap}

From a regional integration perspective, the dangers and potential of digitalization deserve a joint and coherent action. PA member countries are currently facing a challenge to find a common rationale that will allow them to participate actively in the global digital economy and to internalize their potential gains in terms of achieving more transparent management of public resources, improve transparency and enhance the rule of law. To succeed in this endeavor, PA country members will have to curb the local tycoons trapped in the vision inherited from the Washington consensus, and their influence to push for deep privatization of public services.

For instance, the current evolution of some topics related to the deepening of e-commerce in the context of the negotiation of FTAs unveils

18 Erik van der Marel, Hosuk Lee-Makiyama, and Matthias Bauer, “The Costs of Data Localisation: Friendly Fire on Economic Recovery." ECIPE Occasional Paper, no. 2 (2014): 3, https://ecipe.org/publications/dataloc/ 
a very pessimistic panorama for PA countries. The fact that several innovations related to big data, including algorithms and source code applied in the context of artificial intelligence (AI) and the Internet of things (IOT), are intense in knowledge and information makes them sensitive to the configuration of highly regulated environments through stringent IPRs, which can be dangerous as it can weaken and obfuscate the access and use of some of these technologies in developing countries. In this regard, the observation of Ido is relevant as it signals:

Even though many of the recent proposals on e-commerce that have been advanced do not directly address IP issues, they often make reference to exceptions to free flow of information to allow IP protection and could also be applicable to technologies (e.g. machine learning) that could be protected by IP rights. On the one hand, industrialized countries are pushing for free transmission of data and information, including the prohibition of national localization requirements and government use of data, while on the other hand they are concerned about the increasingly difficult enforcement of IP rights in digital economies, leading to a push for both more legal protection (such as for source codes, algorithms, Internet of Things and encrypted technologies) and higher standards of enforcement through various mechanisms (such as broader protection of trade secrets, IP protection as justification for data localization, etc.). It is noteworthy that in some free trade agreements (FTAs) it has been proposed to introduce a restriction on the ability of governments to restrain the cross-border flow of data (Article 14.11 of the СРTPP, for example). ${ }^{19}$

Thus, the fact that three of the five members of the PA are signatory parties of the СРТРP or are taking part in other trade initiatives, such as the DEPA ${ }^{20}$ and TisA, raises serious concerns about the selected approach

19 Vitor Ido, "Intellectual Property and Electronic Commerce: Proposals in the WTO and Policy Implications for Developing Countries," Policy Brief, no.62 (2019): 5, https:// www.southcentre.int/wp-content/uploads/2019/06/PB62_Intellectual-Property-andElectronic-Commerce-Proposals-in-the-WTO-and-Policy-Implications-for-DevelopingCountries_EN.pdf

20 See Digital Economy Partnership Agreement (DEPA). Chile together with New Zealand and Singapore currently negotiate an agreement with the declared aim to deepen and strengthen cooperation in digital areas, establish new international approaches for 
to insert the economic block into the digital economy. It also questions the existence of a real strategy to deal with eventual overlaps between those new negotiated standards and the wide body of recognized rules and binding court decisions regarding diverse matters including IPRs, consumer protection, privacy, right to information, and so forth.

\section{EU's ethos on digital economy as a template for the PA}

Digitalization is a challenging field for developing countries mainly because some of the regulatory interventions can inhibit innovation and delay the consolidation of specific sectors. This complexity increases in the context of regional integration programs, where common views and expectations from like-minded countries must translate into predictable legal frameworks for local enterprises, investors, and consumers altogether. In this regard, the innovative framework contained in the new EU strategy offers some important insights on the institutional framework needed for the construction of coherent rules to deal with the complexities of the digital economy. ${ }^{21}$

For the purpose of this paper, it is important to stress the relevance of instruments like the GDPR to protect the privacy of EU citizens. The change from a Directive towards a Regulation is relevant as it has several implications in terms of the level of local authorities' participation in the enforcement of the regulation and also as it shows the convenience of strong institutionalization as the basis for adequate regulation. In fact, under a Directive, the regulators of member states preserve some level of influence by interpreting and adapting standards to their respective legislations. Regulation on its part is, by definition, more comprehensive, which helps to achieve a high degree of harmonization on the subject matter. In this regard, as we mentioned before, the fact that the Commission has undertaken its regulatory task taking into account different decisions on specific topics among many UE jurisdictions gives an enhanced legitimacy

digital trade issues, and explore new frontiers in the digital economy, including identities, e-payments, cross-border data flows and artificial intelligence. https:/ /www.beehive.govt. $\mathrm{nz} /$ release/nz-joins-chile-and-singapore-talks-digital-economy-partnership

21 See https://ec.europa.eu/digital-single-market/en/right-environment-digital-networksand-services 
to the new regulation. This is crucial as it reveals the relevance of jurisdictional scrutiny of commercial and corporate practices for the follow-up and prospective updating of the regulation.

On the other hand, it is also essential to remember that the PA, as a regional agreement, envisions the framing of deep and clear rules to make commercial traffic more fluid (including on the Internet). ${ }^{22}$ Achieving those goals could be easier within an institutionalized framework where responsibilities and powers are clearly defined. ${ }^{23}$ Unfortunately, in the case of the PA, none of these requirements exists. Member countries have decided to sacrifice institutionalization by assuming the so-called "flexible approach," which certainly simplifies discussions and reduces bureaucratic charges for administrations ${ }^{24}$ at the price of making more difficult the coherent modeling of long-term strategies with defined horizons, goals and sound legal framework.

These previous considerations raise a major question, to what extent is the PA willing to challenge other economic blocs, specifically the Us, by incorporating some EU standards? At first glance, it is arguable that proximity to the legal tradition of continental law would facilitate

22 See Declaración de Paracas (2015) https:/ /alianzapacifico.net/download/declaracionde-paracas-julio-20-de-2015/

23 According to Cerqueira, “...The Pacific Alliance initiative to achieve the free circulation of goods, services, capital and people was taken into account, considering the region's countries share a vision of open economy to the world, where integration emerges as a strategy to address the main challenges in the insertion process into the international economy." Olga María Cerqueira Torres, "The Pacific Alliance: Building Discourses and Realities," in Emerging Markets. The Pacific Alliance. Perspectives \& Opportunities for Latin America, (edited by Mario Torres Jarrín and Jonathan Violante Pica, Salamanca: European Institute of International Studies, 2016, p. 182).

24 In this regard, "The process undertaken by the countries of the Pacific Alliance is located between the two theories; we can say that the Pacific Alliance is a process of "institutionalized regionalization" or "flexible regionalism", because it meets the definition of a process of regionalism, except for the part about creating supranational or community institutions, and therefore, also leans toward the concept of regionalization. The idea of not wishing to develop supranational bodies has long been an aspect of regionalization that the member states of the Alliance have tried to avoid arguing that these institutions generate bureaucracy, rather than efficiency and effectiveness in the process." Torres, Mario. "The new Model of Regional integration for emerging countries in Latin America: The Pacific Alliance". In Emerging Markets. The Pacific Alliance. Perspectives and Opportunities for Latin America, (edited by Mario Torres Jarrín and Jonathan Violante Pica, 19-44. Salamanca: European Institute of International Studies, 2016, p. 24). 
the normative transplantation of some EU standards regulating the digital economy. However, the evidence from the analysis of the two recent agreements achieved by the EU, namely: the Modernisation of the Trade part of the EU-Mexico Global Agreement ${ }^{25}$ and Mercosur-EU Trade Agreement ${ }^{26}$, indicate the absence of so-called "proliferation effects" in relation to the harmonization of regulatory frameworks in the realm of the e-commerce or digital trade. Therefore, it is clear that in the current state of the evolution of the global digital economy, countries and regional blocs seem to prefer the deployment of hidden strategies that allow them to evaluate the full range of technological options and carefully explore which of them better satisfy their specific needs and level of development. For the time being, this climate of regulatory uncertainty seems to be compensated through the inclusion of clauses on the preservation of the "right to regulate" in the context of the negotiation of plurilateral agreements, as well as the establishment of higher self-regulatory standards for technological firms at the local level.

\subsection{Avenues for Judicialization in the PA}

Focusing on the regional actions taken so far, the careful reading to the PA's Additional Protocol unveils a fuzzy approach to digitalization as part of the agenda on e-commerce. Article 13.6.5 establishes:

25 See Modernisation of the Trade part of the EU-Mexico Global Agreement (2018), Chapter 16 on Digital Trade, Article 1.1. "The Parties recognise the economic growth and opportunities provided by digital trade and the importance of adopting frameworks that promote consumer confidence in digital trade and of avoiding unnecessary barriers to its use and development (...) 2. The Parties affirm the right to regulate within their territories to achieve legitimate policy objectives, such as the protection of public health, social services, public education, safety, environment or public morals, social or consumer protection, privacy and data protection, or the promotion and protection of cultural diversity" (emphasis by the author). https://trade.ec.europa.eu/doclib/docs/2018/april/ tradoc_156811.pdf

26 See New Eu-Mercosur Trade Agreement, The Agreement in Principle Brussels, 1 July 2019. Although fairy recent, the document summarizing the negotiating results has no digital economy or electronic commerce provisions. http://trade.ec.europa.eu/doclib/ press/index.cfm?id $=2048$ 
Each Party will assess the adoption of policies that encourage suppliers carrying out their activity through electronic commerce, to comply with the rules of consumer protection in the territory where the consumer is located.

This formulation equals to validate every single self-regulated scheme proposed by tech giants at the country level without providing any adequate system of adjudication that allows for the revision of the conducts undertaken by platforms or other aggregators affecting rights of citizens or endangering public order in the territory of the alliance.

In the same vein, the absence of an institutional arrangement to guarantee consumer rights in relation to e-commerce transactions is likely to increase tensions between digital platforms and individuals interacting in the PA economic area. In such an environment, national governments and private entities could find "solutions" by creating local mechanisms for treating and evacuating these disputes, but whose outcome is prone to result in even more fragmentation and uncertainty for consumers and operators altogether. Hence, such an approach is likely to open the door towards a self-regulatory "race to the bottom" rather than helping to promote regulatory improvement and coherence.

Against this backdrop of conflicting interests, a solution can be drawn through the recourse to existing fora. The Andean Tribunal of Justice (ATJ) is one of the alternatives for undertaking some type of harmonization over the on-going commercial practices related to big data in the PA. This assessment could eventually take the form and procedure of the so-called prejudicial interpretations addressed to national regulators/authorities, clarifying the application of specific rules related to e-commerce or involving the activities of digital platforms.

\subsection{Open regionalism and the Regulation of Conflicting Societal Issues}

One aspect often missing in the discussions on the institutional architecture adopted in the context of open regionalism is that regional integration can thrive and report its benefits when it has the mechanisms for institutional review and follow-up. This is something undoubtedly achievable through the implementation of the Dispute Resolution Mechanisms (DRMs) and namely the establishment of supranational courts. In this regard, it is 
noteworthy the opinion of Biukovic; among the reasons for the dynamic development and proliferation of international DRMs, the author indicates:

$[\mathrm{T}]$ he increased density, volume and complexity of international norms which required correspondingly sophisticated dispute settlement institutions to guarantee the smooth operation of these norms and their accurate interpretation; (2) greater commitment to the rule of law in international relations, at the expense of power-oriented diplomacy; (3) the easing of international tensions, in particular transformation of socialist and centralized economies into market economies; and (4) the positive experience with some international courts and tribunals (e.g., the Court of Justice of the European Communities or the ECJ and the European Court of Human Rights or the ECHR). ${ }^{27}$

Thus, one may argue that the digital economy and its societal effects are indeed complex and sophisticated to the point of challenging the capacity of national institutions to provide efficient solutions without endangering the so-called digital ecosystems. ${ }^{28}$ However, it should be noted that in the past many developing countries also endured a hard experience regulating complex legal issues such as intellectual property or access to genetic resources and were able to give satisfactory regulatory answers grounded on the interpretations provided by supranational courts. ${ }^{29}$ Helfer, Alter, and Guerzovich illustrate this situation:

27 Ljiljana Biukovic, "Dispute Resolution Mechanisms and Regional Trade Agreements: South American and Caribbean Modalities," UC Davis Journal of International Law and Policy 14, no. 2 (2008): 256-257.

28 In this regard, Fairfield and Engel adequately pointed out: “...law must be able to recognize the social and systemic harms caused by the collection, aggregation, and exploitation of data. Courts tend to focus on specific harm to specific complaining individuals, not undivided losses to social welfare. Economists have a different sense of harm. Translating allocated social-welfare harms into actionable legal rules will therefore require patience and creativity." Joshua A. Fairfield and Christoph Engel, "Privacy as a Public Good," Duke Law Journal 65, no. 3 (2015): 425.

29 "The act of balancing between fundamental rights and the imposition of state restrictions to protect public morality or maintain public order is one of the most enduring challenges that courts at all levels have had to tackle in modern history. (...) The task of supranational courts is even more delicate for reasons of legitimacy and capacity, thereby leading them to adopt a less intrusive approach, which, in turn, has led to the adoption 
[E]vidence demonstrates that the Andean legal system has created valuable and enforceable property rights that are strengthened by the ability of private parties to seek ATJ rulings that interpret Andean IP laws. Second, ATJ rulings have changed national court and administrative practices relating to IP rights, especially by requiring agency officials to create an adequate factual record, to justify their decisions with reasons, and to provide clear and fair procedures for contesting parties. Third, the ATJ has been effective as a bulwark against powerful foreign interests that have pressured individual governments to go beyond the WTO-compatible rules that Andean IP law embodies. As a result, Andean IP rules retain many limitations and restrictions that other Latin American countries abrogated in response to pressure from the United States. ${ }^{30}$

Therefore, the enablement of a regional court can favor positive outcomes in terms of social welfare regarding some of the challenging issues arising from the digital economy. At the same time, institutionalization may enhance the legitimacy of the PA process as a whole by creating an authentic uniform source of interpretation of the national regulations and providing the empirical evidence to undertake a coherent regulatory process of harmonization, leading to more transparency and predictability for local and foreign investors.

\section{The Way Forward: Building Up a Strategy to Deal with Digital Platforms}

The speed of information and adaptation to new digital ecosystems requires a clear vision of the impact that global internet governance has at the municipal level. It will be desirable that regional strategies, as conceived and implement inside the EU territory, become the template

of the 'margin of appreciation's doctrine' by many of them." Panaiotis Delimatis, "The Puzzling Interaction of Trade and Public Morals in the Digital Era," (in Trade Governance in the Digital Era, edited by Mira Burri and Thomas Cottier, Cambridge: Cambridge University Press, 2012), 278.

30 Laurence R. Helfer, Karen J. Alter, and Florencia Guerzovich, "Islands of Effective International Adjudication: Constructing an Intellectual Property Rule of Law in the Andean Community," The American Journal of International Law 103, no. 1 (2009): 34. 
for the future and coordinate actions inside the PA. This could contribute to the unification of a global standard on many relevant topics such as data localization, content and censorship, e-commerce, national security, privacy, and data protection.

Although e-commerce is relevant for the dynamism of PA economies, the regulation of such subjects needs to be framed in a more comprehensive understanding of the digital economy as a whole. The current developments of the data-driven economy and the plethora of services and applications arising from the massive algorithmic treatment of information deserves a more careful assessment. Countries should have a more proactive role, studying the impacts of the increasing links between the digital economy and IPR's (namely trade secrets, copyrights, and extended protection to algorithms and source codes). In doing so, they must assess the existence of endogenous capabilities related to sensitive topics such as encryption, cyber security, and interoperability, which eventually can be affected as a consequence of the dynamic assumed by plurilateral trade negotiations. More transparent and evidence-based decision-making processes inside the PA could be more beneficial for this undertaking.

Finally, from an industrial policy perspective, it is absolutely necessary to encourage technology transfer in order to build up the basis for a more ubiquitous economic growth that allows the PA countries to overcome their dependency on natural resources and low skilled labor force. So, tackling seriously the challenges brought by digitalization through the formulation and implementation of ambitious policies committed to the protection of the rights of their citizens would be a first step in the right direction.

\section{References}

Aaronson, Susan Ariel. "What Are We Talking about When We Talk about Digital Protectionism?”. World Trade Review, n.d., 1-37. https:/doi. org/https:/ /doi.org/10.1017/S1474745618000198

Aaronson Susan Ariel, \& Leblond, Patrick. "Another Digital Divide: The Rise of Data Realms and its implications for the WTO." Journal of International Economic Law 21, no. 2 (2018): 245-72. https:/doi.org/ https://doi.org/10.1093/jiel/jgy019

Altenburg, T., and Assmann, C. (Eds.). (2017). Green Industrial Policy. Concept, Policies, Country Expe- riences. Geneva, Bonn: UN Environment; German 
Development Institute / Deutsches Institut für Entwicklungspolitk (DIE).

Biukovic, Ljiljana. "Dispute Resolution Mechanisms and Regional Trade Agreements: South American and Caribbean Modalities." UC Davis Journal of International Law and Policy 14, no. 2 (2008): 255-296.

Burri, Mira, \& Schär, Rachel. "The Reform of the Eu Data Protection Framework: Outlining Key Changes and Assessing Their Fitness for a Data-Driven Economy." Journal of Information Policy 6, (2016): 479-511. https:/doi.org/10.5325/jinfopoli.6.2016.0479

CePAl. La Alianza del Pacifico y el Mercosur. Hacia la convergencia en la diversidad. Santiago de Chile: Naciones Unidas, 2014. Retrieved from https://repositorio.cepal.org/bitstream/handle/11362/37304/1/ S1420838_es.pdf

Cerqueira, T., \& Olga,M. (2016) “The Pacific Alliance: Building Discourses and Realities..." In Emerging Markets. The Pacific Alliance. Perspectives and Opportunities for Latin America, edited by Mario Torres Jarrín and Jonathan Violante Pica, 173-84. Salamanca: European Institute of International Studies, 2016.

Chertoff, Michael. Exploding Data: Reclaiming Our Cyber Security in the Digital Age. London: Grove Press, 2018.

Delimatis, Panagiotis. "The Puzzling Interaction of Trade and Public Morals in the Digital Era." In Trade Governance in the Digital Era, edited by Mira Burri and Thomas Cottier, 276-96. Cambridge: Cambridge University Press, 2012. https:/doi.org/10.1017/ CBO9781139136716.015

"Do Social Media Threaten Democracy? The Economist, November 4, 2017.

Drake, William J., Cerf, Vinton G., \& Kleinwächter, Wolfgang. Future of the Internet Initiative White Paper. Internet Fragmentation: An Overview. World Economic Forum, 2016. In http://www3.weforum.org/ docs/WEF_FII_Internet_Fragmentation_An_Overview_2016.pdf

El-Erian, Mohamed, \& Project Syndicate. Las grandes tecnológicas se topan con el Gran Gobierno. Last modified November 6, 2017. In https://es.weforum.org/agenda/2017/11/ las-grandes-tecnologicas-se-topan-con-el-gran-gobierno/

European Commission. Communication from the Commission to the European Parliament, the European Council, the Council, the European Economic and Social Committee and the Committee of the Regions. Completing a trusted 
Digital Single Market for all. Retrieved from https:/ / ec.europa.eu/ newsroom/dae/document.cfm?doc_id=52283

Fairfield, Joshua A., \& Engel, Christoph. "Privacy as a Public Good." Duke Law Journal 65, no. 3 (2015): 385-457.

Helfer, Laurence R., Alter, Karen J., \& Guerzovich, Florencia. "Islands of Effective International Adjudication: Constructing an Intellectual Property Rule of Law in the Andean Community." The American Journal of International Law 103, no. 1 (2009): 1-47. https:/doi. org/10.2307/20456720

Ido, Vitor. "Intellectual Property and Electronic Commerce: Proposals in the WTO and Policy Implications for Developing Countries." Policy Brief, no.62 (2019): 1-8. Retrieved from https:/ /www.southcentre. int/wp-content/uploads/2019/06/PB62_Intellectual-Propertyand-Electronic-Commerce-Proposals-in-the-WTO-and-PolicyImplications-for-Developing-Countries_EN.pdf

Manjoo, Frahad. "The Upside of Being Ruled by the five Tech Giants." The New York Times International, November 1, 2017. https: / www. nytimes.com/2017/11/01/technology/five-tech-giants-upside.html van der Marel, Erik, Lee-Makiyama, Hosuk, \& Bauer, Matthias. "The Costs of Data Localisation: Friendly Fire on Economic Recovery." ECIPE Occasional Paper, no.2 (2014): 1-19. Retrieved from https:// ecipe.org/publications/dataloc/

Marks, Paul. "Les Robots ces voleurs de travail". Largeur. L'actualité vue par large network, June 24, 2017. Retrieved from https://largeur. $\mathrm{com} / \mathrm{p}=4935$

Modernisation of the Trade part of the EU-Mexico Global Agreement. Retrieved from https://trade.ec.europa.eu/doclib/docs/2018/april/tradoc_156811.pdf

New EU-Mercosur'Trade Agreement, The Agreement in Principle. Retrieved from http:/ / trade.ec.europa.eu/doclib/press/index.cfm?id=2048

Report from the Commission to the European Parliament and the Council on the first annual review of the functioning of the EU-US. Privacy Shield. Retrieved from http://ec.europa.eu/newsroom/just/item- detail. cfm?item_id=605619

“The World's most Valuable Resource." The Economist, May 6, 2017.

Torres, Mario. "The new Model of Regional integration for emerging countries in Latin America: The Pacific Alliance". In Emerging Markets. The Pacific Alliance. Perspectives and Opportunities for Latin 


\section{6}

America, edited by Mario Torres Jarrín and Jonathan Violante Pica, 19-44. Salamanca: European Institute of International Studies, 2016. Wolf, Martin. 2017, “Taming the masters on the tech universe." Financial Times, November 14, 2017. Retrieved from https://www.ft.com/ content/45092c5c-c872-11e7-aa33-c63fdc9b8c6c 